\title{
32. BASALTIC GLASSES FROM THE MARIANA TROUGH ${ }^{1}$
}

\author{
Patricia Fryer, ${ }^{2}$ John M. Sinton, and John A. Philpotts, Hawaii Institute of Geophysics, \\ University of Hawaii, Honolulu, Hawaii
}

\begin{abstract}
The tectonic character oceanic crustal generation in the Mariana Trough, an active, extensional, back-arc basin, is similar in many ways to that at normal mid-ocean ridges. Thus it might be expected that the basalts erupted in the basin would be like normal mid-ocean ridge basalt. Basaltic glasses from each environment show consistent differences, however, Mariana Trough basaltic glasses have lower total iron and $\mathrm{TiO}_{2}$ and higher $\mathrm{Al}_{2} \mathrm{O}_{3}$ at a given $\mathrm{MgO}$ concentration. The rare earth patterns for Mariana Trough glasses are essentially flat relative to chondrite. Incompatible element abundances are higher for the trough basalts than for ridge basalts. The volatile content of trough basalts is high (approximately $1 \% \mathrm{H}_{2} \mathrm{O}$ ).

These compositional characteristics are also true of basalts from other active marginal basins and suggest that the sources of these lavas differ from those of normal mid-ocean ridge basalts. Part of the reason for these differences may be the peculiar tectonic environment of active back-arc basins, in particular their location above the subducted oceanic lithospheric plate.
\end{abstract}

\section{INTRODUCTION}

\section{Geologic Setting}

The Mariana Trough (Fig. 1) is a young extensional basin situated between the volcanically active Mariana Island arc and the West Mariana Ridge, a remnant arc. Spreading began there approximately $6 \mathrm{Ma}$ (Fryer and Hussong, this volume). Patterns of magnetic anomalies throughout the basin (Hussong and Fryer, 1980), seismicity in the central portion (Hussong and Sinton, 1979), the morphology of the spreading center (Uyeda and Hussong, 1978), and the increase in seismic velocities with age of crustal layers (Ambos and Hussong, 1979) are similar to features of slowly spreading segments of normal mid-ocean ridges. There are a number of ways in which the Mariana Trough differs tectonically from normal mid-ocean ridges, however. It is situated very close to a convergent plate boundary, and the changes of spreading direction within the basin noted by Hussong and Fryer (1980) are probably related to the convergence. At $18^{\circ} \mathrm{N}$ the spreading rate is much slower $(1.65 \mathrm{~cm} / \mathrm{y}$., according to Hussong and Fryer [1980]) and the central graben is deeper ( $4600 \mathrm{~m}$, Fryer and Hussong [this volume]) than encountered at other spreading ridges. Seismic refraction studies show that crust and mantle velocities are lower than at mid-ocean ridges (Ambos and Hussong, 1979). Gravity models suggest a mass deficiency at depth, indicating mantle densities that are lower than normal (Sager, 1980). It is suspected that the degree of fracturing of the crust, at least at this latitude, is greater than is usually encountered at mid-ocean ridges (Ambos, 1980; Fryer and Hussong, this volume). The fractured nature of the crust may account for the low-magnitude earthquakes $(M<$

\footnotetext{
${ }_{2}^{1}$ Initial Reports of the Deep Sea Drilling Project, Volume 60.

2 Present address: Department of Geological and Geophysical Sciences, Princeton University, Princeton, New Jersey.
}

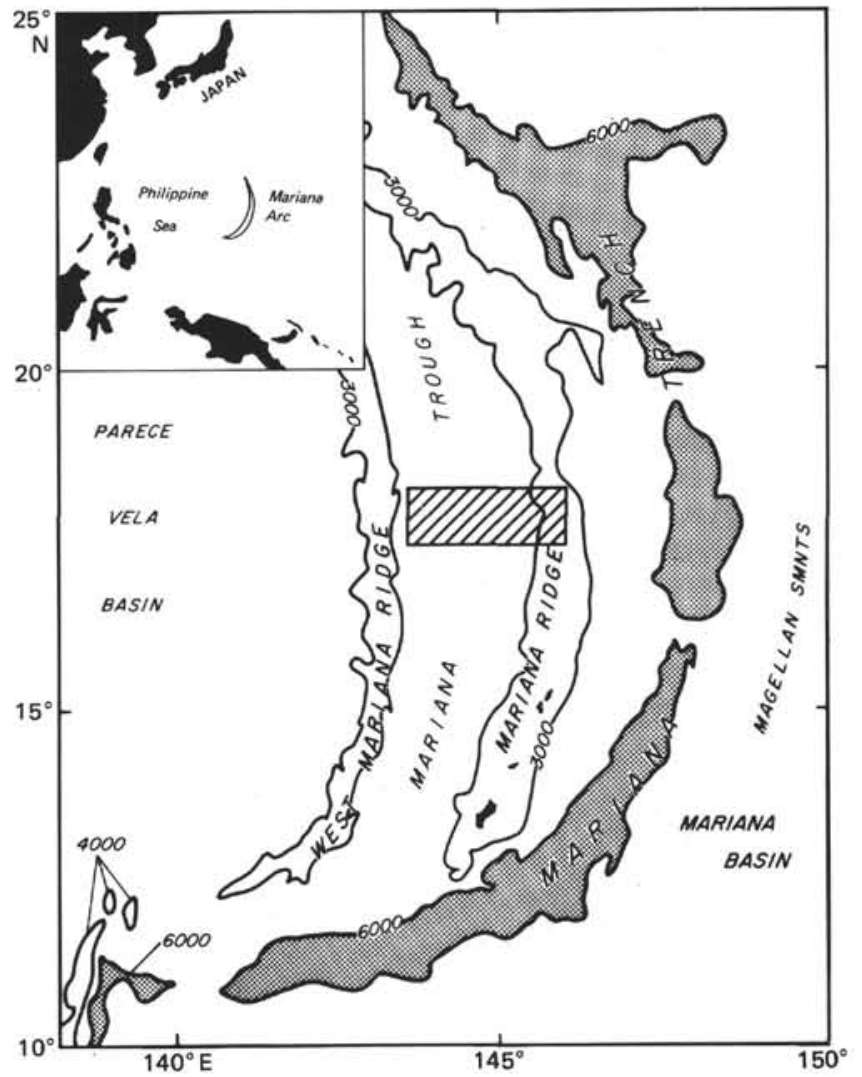

Figure 1. Position of the Mariana arc-basin system in the western $\mathrm{Pa}$ cific. DSDP Sites 453 to 456 were drilled in the Mariana Trough.

3; Hussong and Sinton, 1979) and the high degree of hydrothermal activity in the region (see site chapters for Sites 453 and 456 and Uyeda and Horai, this volume).

These similarities and differences of mid-ocean ridge and Mariana Trough tectonics raise some basic questions concerning magma genesis in the back-arc basin. 
How do Mariana Trough basalts and other back-arc basin basalts compare with mid-ocean ridge basalt (MORB)? How is magma composition related to the tectonic setting of the Mariana Trough? Have these relationships changed with time?

\section{Sampling}

Prior to 1977, samples were dredged from the central portion of the Mariana Trough (Fig. 2) on two cruises by the Scripps Institution of Oceanography. The compositions of some of these samples are reported in Hart et al. (1972) and Meijer (1976). In preparation for Leg 60 of the Deep Sea Drilling Project, detailed surveys of the prospective sites were carried out by the Hawaii Institute of Geophysics (HIG) during 1976 and 1977. Dredging was done in the vicinity of each proposed drilling site, but only those stations from the central portion of the basin yielded fresh basalts. During Leg 60 , four locations were drilled in the trough (Fig. 2). Of these, only two sites ( 454 and 456 ) penetrated igneous rocks of the marginal basin crust.

Many of the samples collected in the dredging operations and in subsequent DSDP drilling are fragments of basaltic pillow lavas. They have glassy rims $(0.1-1 \mathrm{~cm}$ thick), spherulitic to variolitic margins (up to $4 \mathrm{~cm}$ thick), and fine-grained hypocrystalline interiors. The rocks from dredge hauls 13 and 14 are sparsely porphyritic, containing skeletal microphenocrysts of plagioclase and olivine, which generally occcur in small crystal clumps. Spinel inclusions occur in olivine and plagioclase phenocrysts in some of the dredge 13 and 14 samples. A large number of aphyric and porphyritic pillow fragments were retrieved in dredge haul 3. In addition to skeletal olivine and plagioclase in the dredge 3 pillow fragments, there are also some rounded and embayed plagioclase and pyroxene phenocrysts. No spinel was observed in any of these rocks. The groundmass of the rocks from all three dredge locations varies from hyaline to hypocrystalline. In most, microlitic to very small skeletal laths of plagioclase are the dominant groundmass phase. Many of the rocks contain globulites and margarites of pyroxene(?). Minute grains of olivine occur in the groundmass of some of the rocks from dredge 13. Most of the rocks chosen for this study are very fresh. Some of them contain a small amount of secondary clays occurring as vesicle linings or vein fillings. The vesicularity of these rocks is generally greater than $10 \%$ by volume. The thin sections described in Table 1 were cut from the outer glassy portions of the samples, where vesicle development is lowest.

The DSDP samples are aphyric to sparsely porphyritic with plagioclase and olivine phenocrysts. Although the glass samples from the cores were too small to permit thin sectioning, descriptions of the lithologic units from which these samples were taken are included in the petrology sections of site chapters 454 and 456 .

Small chips from the glassy rims of 30 of the freshest pillow fragments retrieved in HIG dredge hauls 3,13 , and 14 were chosen for analysis. Only seven pillow fragments containing fresh glassy basalt were recovered from DSDP sites in the Mariana Trough. All of these were analyzed. In addition to these, a number of samples of basaltic glass from several other marginal basins were analyzed-one from the Lau Basin, two from the Parece Vela Basin, and five from the Scotia Sea. The Lau Basin, located between the Lau and Tonga Kermadec Ridges, shows evidence of currently active extension but appears to have a complicated pattern of spreading (Hawkins, 1976a). Both the Parece Vela Basin and the Scotia Sea show normal mid-ocean ridge spreading patterns (Langseth and Mrozowski, in press; Barker, 1970). The Parece Vela Basin, bounded on the west by the Palau-Kyushu Ridge and on the east by the West Mariana Ridge, was actively spreading from Oligocene to Miocene time (Scott et al., in press). The Scotia Sea is a currently active marginal basin similar in many respects to the Mariana Trough (Barker, 1970; Saunders et al., in press). Comparison of Mariana Trough basalts with basalts from these other marginal basins allows us to examine the consistency of compositions among marginal basin lavas.

\section{ANALYTICAL PROCEDURES}

Although numerous investigators have studied the composition of MORB (Engel and Engel, 1964; Miyashiro et al., 1970; Byerly et al., 1975; Melson et al., 1976), the rocks which were studied vary widely in degree of crystallinity and in character and extent of alteration. Furthermore, the techniques used to analyze these rocks differ considerably. Most commonly the basalts collected in the ocean ridge provinces are fragments of pillow lava with quenched, glassy rims representing the liquid composition of the lavas at the time they were erupted. If only fresh portions of the glassy rims are chosen for analysis, the problems of variation in degree of crystallinity and alteration among samples can be avoided. Thousands of basaltic glasses from midocean ridge provinces have been analyzed for major element composition by microprobe at the Smithsonian Institution (Melson et al., 1976). The technique is described in Byerly et al. (1975). The back-arc basin glasses chosen for the present study were analyzed by microprobe (Table 2) at the Smithsonian Institution using the same technique as for MORB analyses. Thus the Smithsonian glass file provides a large body of data with which to compare the major element composition of our back-arc basin samples.

Analysis of selected samples for certain rare earth (Ce, Nd, Sm, Eu, Gd, Dy, Er, Yb, Lu) and other minor and trace element $(\mathrm{Li}, \mathrm{K}, \mathrm{Rb}, \mathrm{Sr}, \mathrm{Ba})$ compositions (Table 3 ) were performed by mass spectrometry at the Hawaii Institute of Geophysics, using stable isotope dilution methods. This technique is described in Webster (1960) and Schnetzler et al. (1967) as modified by Schuhmann et al. (1980).

\section{CHEMICAL ANALYSES}

Basalts from normal mid-ocean ridge segments (N-MORB) - that is, those not influenced by the peculiar chemistry of melting anomalies ("mantle plumes" 


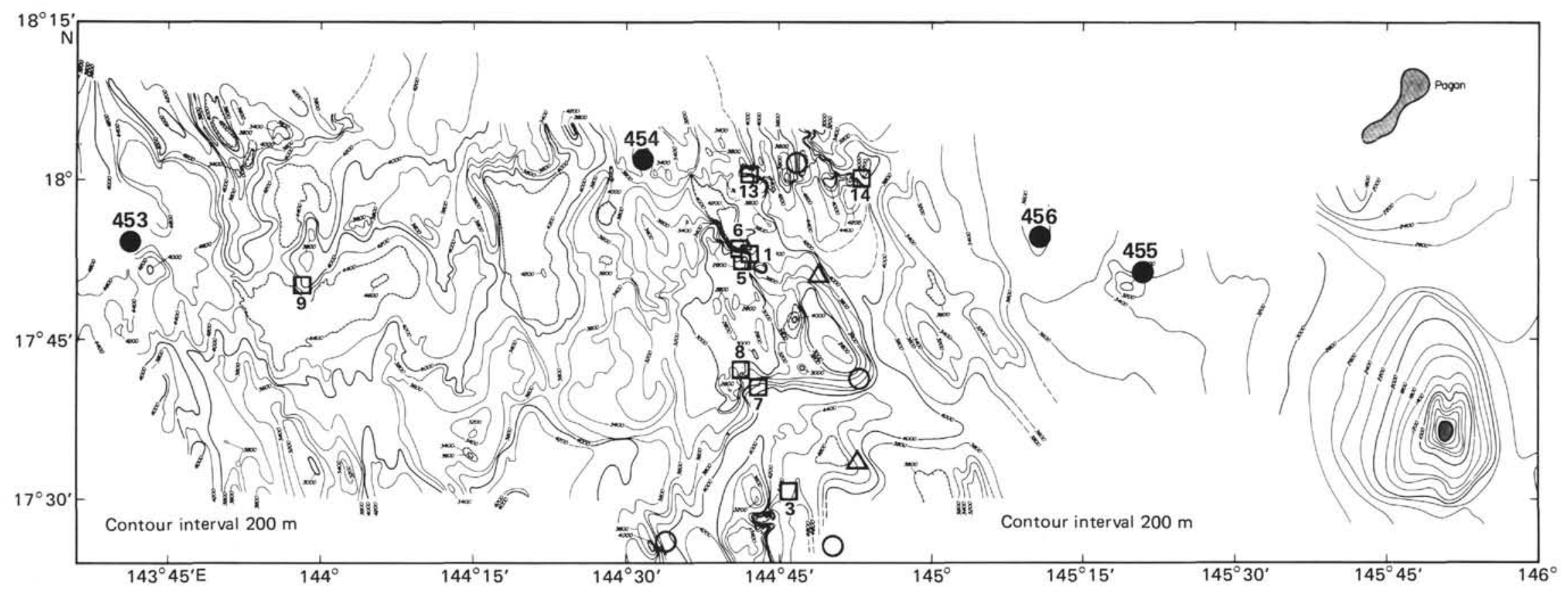

Figure 2. Bathymetry map of the Mariana Trough at about $18^{\circ} \mathrm{N}$ showing locations of HIG dredge sites (open squares) and DSDP Sites 453 to 456 (filled circles). Open triangles and open circles are locations of SIO dredges (Hart et al., 1972). Glasses analyzed are from dredge sites 3, 13, and 14 and DSDP Site 454. 
Table 1. Petrologic description of basalt samples dredged from the Mariana Trough. ${ }^{\mathrm{a}}$

\begin{tabular}{|c|c|c|c|c|c|c|c|c|c|c|c|}
\hline \multirow[b]{2}{*}{ Sample ${ }^{b}$} & \multicolumn{4}{|c|}{ Phenocrysts } & \multicolumn{3}{|c|}{ Groundmass } & \multirow[b]{2}{*}{ Ores } & \multirow[b]{2}{*}{ Glass } & \multirow[b]{2}{*}{ Alt. } & \multirow[b]{2}{*}{ Ves. } \\
\hline & $\mathrm{Pl}$. & Ol. & Px. & Sp. & Pl. & Ol. & Px. & & & & \\
\hline M0302 & & 2 & & & 10 & & 10 & $\mathrm{Tr}$ & 47 & 30 & 1 \\
\hline M0310 & 12 & 5 & & & 13 & & 10 & & 67 & & 4 \\
\hline M0338 & 8 & 1 & $\operatorname{Tr}$ & & 15 & & 18 & $\operatorname{Tr}$ & 54 & & 3 \\
\hline M0370 & 2 & 2 & & & 3 & & 3 & & 85 & & 5 \\
\hline M0373 & 7 & 1 & & & 15 & & 18 & & 45 & 4 & 10 \\
\hline M0379 & 1 & 2 & & & 20 & & 20 & & 67 & 5 & 5 \\
\hline M0380 & 5 & 2 & & & 3 & & 1 & & 86 & 1 & 2 \\
\hline M03100 & 8 & 6 & & & 3 & & 2 & $\mathrm{Tr}$ & 77 & & 3 \\
\hline M03101 & 6 & 4 & & & 5 & & 4 & & 71 & 2 & 8 \\
\hline M03102 & & & & & 1 & & & & 97 & & 2 \\
\hline M1300 & & 2 & & $\operatorname{Tr}$ & 15 & 4 & 12 & $\mathrm{Tr}$ & 57 & 2 & 7 \\
\hline M1316 & 4 & 2 & & & 2 & & 3 & 1 & 82 & 3 & 3 \\
\hline M1330 & 5 & 3 & & & 4 & & 10 & & 66 & & 12 \\
\hline M1349 & 4 & 3 & & & 3 & & 5 & $\mathrm{Tr}$ & 76 & $\operatorname{Tr}$ & 8 \\
\hline M1355 & 2 & 2 & & & 15 & 5 & 10 & & 61 & 2 & 3 \\
\hline M1371 & 3 & 2 & & & 7 & & 5 & & 68 & & 15 \\
\hline M1372 & 3 & 1 & & $\operatorname{Tr}$ & 3 & 2 & 5 & & 84 & $\operatorname{Tr}$ & 1 \\
\hline M1380 & & $\mathrm{Tr}$ & & $\mathrm{Tr}$ & 10 & 3 & 10 & & 65 & 3 & 8 \\
\hline M1381 & & 1 & & $\mathrm{Tr}$ & 8 & $\mathrm{Tr}$ & 10 & & 72 & 1 & 7 \\
\hline M1396 & 1 & 2 & & $\operatorname{Tr}$ & 10 & 1 & 8 & & 74 & $\operatorname{Tr}$ & 3 \\
\hline M1417 & 20 & 6 & & & & & & & 64 & & 10 \\
\hline M1419 & 1 & 1 & & & 5 & & 3 & $\operatorname{Tr}$ & 82 & & 7 \\
\hline M1441 & 2 & 1 & & & 3 & & 1 & 1 & 89 & & 3 \\
\hline M1463 & 10 & 6 & & & & & & $\mathrm{Tr}$ & 79 & 3 & 1 \\
\hline M14104 & 1 & 3 & & 1 & 10 & & $\mathrm{Tr}$ & & 64 & & 5 \\
\hline M14106 & $\mathrm{Tr}$ & 3 & & 1 & 5 & & 5 & & 80 & & 10 \\
\hline
\end{tabular}

Note: $\mathrm{Pl} .=$ plagioclase Ol. = olivine; $\mathrm{Px} .=$ pyroxene; $\mathrm{Sp} .=$ spinel; Ores = opaque minerals; Alt. $=$ secondary minerals (mainly brown and green clays); Ves. $=$ vesicles

a Volume percent estimated from thin section.

b Samples M03, M13, and M14 are from dredges 3, 13, and 14 (Fig. 2).

or "'hot spots") or propagating rifts-have a distinctive set of major element compositional traits (see Table 2). These basalts have low values of $\mathrm{K}_{2} \mathrm{O}(0.1-0.5$ wt. \%), $\mathrm{TiO}_{2}(1.0-2.0 \mathrm{wt} . \%)$, total iron $(6.5-12.0 \mathrm{wt} . \%)$, and $\mathrm{P}_{2} \mathrm{O}_{5}(0.08-0.23$ wt. \%) but high values of $\mathrm{CaO}$ (10.5-12.5 wt. \%) and $\mathrm{Al}_{2} \mathrm{O}_{3}(15.0-18.0$ wt. \%) (Engel and Engel, 1964; Engel et al., 1965; Aumento, 1968; Miyashiro et al., 1970; Kay et al., 1970; Melson et al., 1976). Major element composition of the back-arc basin (BAB) basaltic glasses for our study do show these characteristics, but the BAB glasses also have a distinctive set of compositional traits and show certain differences from those of N-MORB glasses. A comparison of liquid trends on $\mathrm{MgO}$ variation diagrams (Fig. 3A-C) for $\mathrm{N}-\mathrm{MORB}$ versus $\mathrm{BAB}$ glasses shows displacement of the trends for total iron $\left(\mathrm{FeO}^{t}\right)(2.5 \mathrm{wt} . \%<\mathrm{MORB})$, $\mathrm{TiO}_{2}(0.5$ wt. $\%<\mathrm{MORB}), \mathrm{Al}_{2} \mathrm{O}_{3}(2.0$ wt. $\%>$ MORB). When the BAB glasses are compared with MORB glasses affected by proximity to mantle plume or hot spot sources (P-MORB), the $\mathrm{FeO}^{\mathrm{t}}$ and $\mathrm{Al}_{2} \mathrm{O}_{3}$ trends remain distinct, whereas that of $\mathrm{TiO}_{2}$ does not (Fig. $3 \mathrm{C})$.

Some trace element abundances also help to distinguish MORB and the BAB glasses. N-MORB shows light rare earth element (REE) depletion, and P-MORB shows light REE enrichment with respect to chondritic abundances (Schilling, 1975b; Sun et al., 1979). REE patterns for the Mariana Trough glasses are essentially flat with respect to chondrite and fall near the upper limit for MORB (Fig. 4). Plots of REE for whole-rock samples from the Scotia Sea show patterns similar to the Mariana Trough glasses (Tarney et al., 1977). REE patterns of $\mathrm{BAB}$ are more similar to those of MORB transi- tional between P- and N-MORB (T-MORB), except that $\mathrm{BAB}$ lack the slightly concave upward pattern of the light REE that is characteristic of T-MORB (e.g., White and Bryan, 1977; Sun et al., 1979).

Incompatible element abundances are generally higher for the Mariana Trough glasses, and ratios of $\mathrm{K} / \mathrm{Ba}$, $\mathrm{Ce} / \mathrm{Ba}, \mathrm{Sr} / \mathrm{Ba}$, and $\mathrm{K} / \mathrm{Rb}$ are lower than $\mathrm{N}-\mathrm{MORB}$ but similar to T- and P-MORB (Table 3).

\section{DISCUSSION}

This chapter presents the results of initial investigations of the basaltic glasses gathered in site surveys and during Leg 60 drilling in the Mariana Trough. Detailed interpretation of these data will be presented elsewhere. At this stage of our investigations it is important to note the major and distinctive characteristics of the Mariana Trough glass compositions and to consider whether these compositions imply tectonic control of magma genesis in the active marginal basin environment.

Previous investigations of $\mathrm{BAB}$ basalts have led to the conclusion that, with regard to major element composition, there is little difference between MORB and BAB basalts (Hart et al., 1972; Hawkins, 1974, 1976a, 1976b, 1977; Hawkins and Batiza, 1975; Gill, 1976; Tarney et al., 1977; Saunders et al., in press; Mattey et al., in press). But trace element analysis shows that in many cases the BAB lavas are intermediate between MORB and basalt of the island arc tholeiitic series (Gill, 1976; Saunders et al., in press; Tarney et al., 1977; Fryer, 1980; Wood et al., this volume). Most of these investigations deal exclusively with whole-rock analyses. The data here demonstrate that major element compositions of BAB basaltic glasses are distinctive. The trends for $\mathrm{BAB}$ and $\mathrm{MORB}$ glasses in $\mathrm{MgO}$ variation diagrams (Fig. 3) indicate control by mineral fractionation, primarily olivine, for the lavas erupted in these environments.

The observed depletion in total iron and $\mathrm{TiO}_{2}$ and enrichment in $\mathrm{Al}_{2} \mathrm{O}_{3}$ may be related to mineralogy of the source. For example, melting of a plagioclase peridotite at low pressure could produce enrichment in $\mathrm{Al}_{2} \mathrm{O}_{3}$ and consequent relative depletion in iron and $\mathrm{TiO}_{2}$. It seems more likely that the major element composition of the $\mathrm{BAB}$ glasses reflects the extent to which the volatile content of the lavas controls the order and composition of phases crystallizing during fractionation of the magmas. Glass samples from the Mariana Trough and the Scotia Sea have high contents of $\mathrm{H}_{2} \mathrm{O}, \mathrm{CO}_{2}, \mathrm{~F}$, and $\mathrm{Cl}$ (Garcia et al., 1979). Under hydrous conditions the field of stability of olivine is greatly expanded, plagioclase crystallization is inhibited, and the relative amounts of crystallization of pyroxene and amphibole vary (Hamilton, 1964; Green and Ringwood, 1968). These effects may explain the relative depletion in iron and $\mathrm{TiO}_{2}$ and the enrichment in $\mathrm{Al}_{2} \mathrm{O}_{3}$ characteristic of $\mathrm{BAB}$ lavas.

We are currently analyzing glass samples from the Parece Vela and Lau basins for volatile content. If high volatile content of BAB lavas is a consistent trait, the presence of volatiles may be explained in a number of ways: (1) Alteration of submarine lavas, particularly in regions with high hydrothermal activity, would increase 
Table 2. Results of microprobe analysis of basaltic glasses from the Mariana Trough, Lau Basin, Parece Vela Basin, and the Scotian Sea.

\begin{tabular}{|c|c|c|c|c|c|c|c|c|c|c|c|}
\hline Sample ${ }^{a}$ & $\mathrm{SiO}_{2}$ & $\mathrm{Al}_{2} \mathrm{O}_{3}$ & $\mathrm{FeO}^{\mathrm{t}}$ & $\mathrm{MgO}$ & $\mathrm{CaO}$ & $\mathrm{Na}_{2} \mathrm{O}$ & $\mathrm{K}_{2} \mathrm{O}$ & $\mathrm{TiO}_{2}$ & $\mathrm{P}_{2} \mathrm{O}_{5}$ & Total & Source $^{b}$ \\
\hline M0302 & 48.85 & 17.04 & 9.81 & 8.10 & 10.72 & 2.98 & 0.20 & 1.18 & 0.15 & 99.03 & MT \\
\hline M0310 & 51.79 & 15.95 & 8.99 & 6.35 & 10.60 & 3.25 & 0.33 & 1.53 & 0.18 & 98.97 & MT \\
\hline M0311 & 52.53 & 16.01 & 9.58 & 5.16 & 9.14 & 3.73 & 0.41 & 1.75 & 0.21 & 98.52 & MT \\
\hline M0338 & 51.24 & 16.10 & 8.94 & 6.16 & 10.39 & 3.36 & 0.38 & 1.53 & 0.18 & 98.28 & MT \\
\hline M0338 & 51.59 & 15.98 & 9.11 & 6.17 & 10.56 & 3.30 & 0.34 & 1.54 & 0.16 & 98.75 & MT \\
\hline M0360 & 51.77 & 15.55 & 9.36 & 6.74 & 11.04 & 3.07 & 0.25 & 1.63 & 0.16 & 99.57 & MT \\
\hline M0370 & 50.88 & 16.03 & 8.42 & 6.65 & 10.68 & 2.96 & 0.28 & 1.31 & 0.16 & 97.37 & MT \\
\hline M0373 & 51.76 & 15.92 & 8.82 & 6.39 & 10.55 & 3.27 & 0.26 & 1.52 & 0.16 & 98.65 & MT \\
\hline M0379 & 49.44 & 17.12 & 9.79 & 7.49 & 11.01 & 2.84 & 0.25 & 1.15 & 0.12 & 99.21 & MT \\
\hline M0380 & 51.47 & 15.23 & 9.61 & 6.40 & 10.56 & 3.27 & 0.26 & 1.74 & 0.17 & 98.71 & MT \\
\hline M03100 & 50.63 & 15.31 & 9.81 & 6.25 & 10.52 & 3.35 & 0.31 & 1.75 & 0.20 & 98.13 & MT \\
\hline M03101 & 51.90 & 15.55 & 9.31 & 6.79 & 11.32 & 3.01 & 0.24 & 1.56 & 0.19 & 99.87 & MT \\
\hline M03102 & 50.44 & 15.56 & 9.30 & 6.57 & 10.43 & 3.40 & 0.36 & 1.47 & 0.17 & 97.70 & MT \\
\hline M1300 & 51.04 & 17.15 & 7.59 & 7.54 & 11.84 & 2.70 & 0.17 & 1.06 & 0.12 & 99.09 & MT \\
\hline M1316 & 51.50 & 16.22 & 8.51 & 6.67 & 11.25 & 2.86 & 0.20 & 1.35 & 0.16 & 98.56 & MT \\
\hline M1330 & 51.27 & 15.96 & 8.43 & 6.71 & 11.21 & 2.86 & 0.20 & 1.37 & 0.15 & 98.16 & MT \\
\hline M1349 & 51.72 & 16.26 & 8.68 & 6.78 & 11.21 & 3.00 & 0.18 & 1.37 & 0.15 & 99.35 & MT \\
\hline M1355 & 51.64 & 16.37 & 8.55 & 7.42 & 11.30 & 3.09 & 0.12 & 1.30 & 0.13 & 99.92 & MT \\
\hline M1371 & 51.43 & 16.40 & 8.68 & 6.83 & 11.21 & 3.13 & 0.20 & 1.37 & 0.13 & 99.38 & MT \\
\hline M1372 & 51.40 & 16.19 & 8.56 & 7.00 & 11.27 & 3.00 & 0.21 & 1.39 & 0.16 & 99.18 & MT \\
\hline M1380 & 50.54 & 17.13 & 7.71 & 7.68 & 11.73 & 3.00 & 0.19 & 1.13 & 0.14 & 99.25 & MT \\
\hline M1381 & 50.67 & 17.08 & 7.66 & 7.93 & 11.84 & 2.93 & 0.18 & 1.09 & 0.13 & 99.51 & MT \\
\hline M1396 & 51.27 & 17.28 & 7.72 & 7.36 & 11.80 & 2.81 & 0.20 & 1.13 & 0.13 & 99.70 & MT \\
\hline M1410 & 50.51 & 17.59 & 8.01 & 7.01 & 11.65 & 2.67 & 0.26 & 1.15 & 0.13 & 98.98 & MT \\
\hline M1417 & 49.38 & 17.89 & 8.68 & 5.77 & 12.06 & 3.61 & 0.23 & 1.46 & 0.17 & 99.25 & MT \\
\hline M1419 & 50.68 & 17.20 & 7.89 & 6.90 & 11.44 & 2.66 & 0.27 & 1.14 & 0.14 & 98.32 & MT \\
\hline M1441 & 51.22 & 16.32 & 9.17 & 6.94 & 11.20 & 3.11 & 0.19 & 1.39 & 0.16 & 99.70 & MT \\
\hline M1463 & 50.15 & 15.98 & 9.76 & 6.89 & 11.84 & 3.49 & 0.18 & 1.59 & 0.18 & 100.06 & MT \\
\hline M14104 & 50.83 & 17.19 & 7.74 & 7.21 & 11.59 & 2.59 & 0.20 & 1.13 & 0.16 & 98.64 & MT \\
\hline M14106 & 49.96 & 16.92 & 7.83 & 7.26 & 11.52 & 2.65 & 0.27 & 1.06 & 0.13 & 97.60 & MT \\
\hline M454-4-CC & 50.24 & 16.56 & 7.73 & 8.09 & 12.19 & 2.42 & 0.19 & 1.01 & 0.12 & 98.55 & MT \\
\hline M454-8-1 & 50.17 & 16.88 & 7.55 & 7.89 & 12.46 & 2.35 & 0.19 & 0.90 & 0.14 & 98.53 & MT \\
\hline M454-11-1 & 50.92 & 17.08 & 7.48 & 7.94 & 12.72 & 2.44 & 0.18 & 0.89 & 0.11 & 99.76 & MT \\
\hline M454-14-1 & 52.69 & 17.01 & 7.86 & 6.88 & 11.10 & 2.67 & 0.26 & 1.19 & 0.12 & 99.78 & MT \\
\hline M454-14-1 & 52.79 & 16.83 & 7.89 & 7.18 & 10.99 & 2.67 & 0.24 & 1.15 & 0.13 & 99.87 & MT \\
\hline M454-16-1 & 52.34 & 16.78 & 7.92 & 6.89 & 11.06 & 2.54 & 0.26 & 1.17 & 0.15 & 99.11 & MT \\
\hline M454-19-1 & 51.08 & 16.58 & 8.32 & 7.30 & 11.85 & 2.65 & 0.15 & 1.13 & 0.13 & 99.19 & MT \\
\hline SS20.13 & 51.70 & 16.23 & 8.14 & 6.99 & 11.14 & 3.11 & 0.25 & 1.37 & 0.20 & 99.13 & SS \\
\hline SS20.31 & 52.16 & 16.19 & 8.12 & 7.04 & 11.21 & 3.07 & 0.26 & 1.42 & 0.17 & 99.64 & SS \\
\hline SS20.35 & 51.69 & 16.36 & 7.99 & 7.09 & 11.24 & 3.09 & 0.23 & 1.34 & 0.16 & 99.19 & SS \\
\hline SS20.43 & 51.58 & 16.39 & 8.22 & 7.08 & 11.21 & 3.10 & 0.25 & 1.37 & 0.18 & 99.46 & SS \\
\hline SS23.4 & 51.34 & 15.99 & 8.91 & 6.69 & 11.36 & 3.38 & 0.35 & 1.54 & 0.20 & 99.76 & SS \\
\hline L203-6-3 & 51.99 & 16.18 & 7.52 & 7.14 & 12.64 & 2.07 & 0.28 & 0.70 & 0.16 & 98.68 & LB \\
\hline P54-8-1 & 50.11 & 17.36 & 9.29 & 8.06 & 11.26 & 2.94 & 0.11 & 0.99 & 0.11 & 100.23 & PVB \\
\hline P149-17-3 & 48.90 & 16.58 & 9.36 & 7.59 & 11.76 & 2.43 & 0.22 & 0.96 & 0.10 & 97.60 & PVB \\
\hline MORB-1 & 49.34 & 17.04 & 9.97 & 7.19 & 11.72 & 2.73 & 0.16 & 1.49 & 0.16 & 99.80 & A \\
\hline MORB-2 & 50.47 & 15.31 & 10.42 & 7.46 & 11.48 & 2.64 & 0.16 & 1.58 & 0.13 & 99.65 & M \\
\hline
\end{tabular}

Note: Analyst, Timothy O'Hearn.

a Samples M03, M13, and M14 are from dredges 3, 13, and 14, respectively (Fig. 2). M454 samples are from DSDP Site 454.

b $\mathrm{MT}=$ Mariana Trough basaltic glass (this study); LB = Lau Basin basaltic glass (this study); PVB = Parece Vela Basin basaltic glass (this study); $\mathrm{SS}=$ Scotia Sea basaltic glass (this study); $\mathrm{A}=$ average mid ocean ridge basalt (Aumento, 1968); $\mathrm{M}=$ average of basaltic glass from normal sections of the East Pacific Rise and the Mid-Atlantic Ridge; total: 64 samples (Melson et al., 1976).

c Duplicate analysis.

Table 3. Rare-earth element and large ion lithophile element abundances for selected basaltic glass samples from the Mariana Trough.

\begin{tabular}{lcccccc}
\hline Sample $^{\mathrm{a}}$ & M0379 & M03102 & M1300 & M1316 & M1417 & M1419 \\
\hline $\mathrm{Ce}$ & 11.2 & 16.1 & 10.5 & 11.5 & 15.0 & 11.6 \\
$\mathrm{Nd}$ & 8.36 & 12.3 & 8.64 & 10.3 & 10.9 & 9.52 \\
$\mathrm{Sm}$ & 2.73 & 3.82 & 2.66 & 3.38 & 3.19 & 2.91 \\
$\mathrm{Eu}$ & 1.08 & 1.38 & 1.03 & 1.25 & 1.25 & 1.08 \\
$\mathrm{Gd}$ & & & 3.83 & 4.49 & & \\
$\mathrm{Dy}$ & 4.72 & 5.60 & 4.24 & 5.22 & 4.63 & 4.64 \\
$\mathrm{Er}$ & 3.28 & 3.48 & 2.51 & 3.27 & 2.90 & 2.94 \\
$\mathrm{Yb}$ & 3.18 & 3.27 & 2.40 & 3.09 & 2.92 & 2.67 \\
$\mathrm{Lu}$ & 0.47 & 0.50 & 0.35 & 0.45 & 0.42 & 0.40 \\
$\mathrm{Ba}$ & 38.4 & 75.2 & 31.0 & 35.1 & 66.0 & 48.4 \\
$\mathrm{~K}$ & 1729 & 2338 & 1758 & 1993 & 1778 & 2350 \\
$\mathrm{Rb}$ & 2.34 & 3.93 & 2.48 & 3.00 & 1.37 & 3.52 \\
$\mathrm{Sr}$ & 147 & 182 & 176 & 161 & 212 & 166 \\
$\mathrm{Li}$ & 5.16 & 7.01 & 5.20 & 6.05 & 5.95 & 5.89 \\
\hline
\end{tabular}

a See Note b, Table 1. the volatile content of the lavas. However, the samples chosen for analysis in this study were fresh glasses, thus the problem of alteration does not apply. (2) Logging data (density) from Site 454 in the Mariana Trough indicate that some flows may be interbedded with sediment layers (see site chapter for Site 454 , this volume). It has been suggested that the environment at this site would be suitable for sediment assimilation into the lavas erupted there (Wood et al., this volume). It is possible that the high water content of the glasses is a result of assimilation of sediment into the lavas. It seems unlikely, however, that the high water content also noted in inclusions in plagioclase phenocrysts (xenocrysts?) by Garcia et al. (1979) in the same samples derived from the incorporation of sediment into the lava. (3) Finally, the high volatile content of the BAB lavas may be related to the tectonic environment in which they formed. Each of the active back-arc basins from which we have 

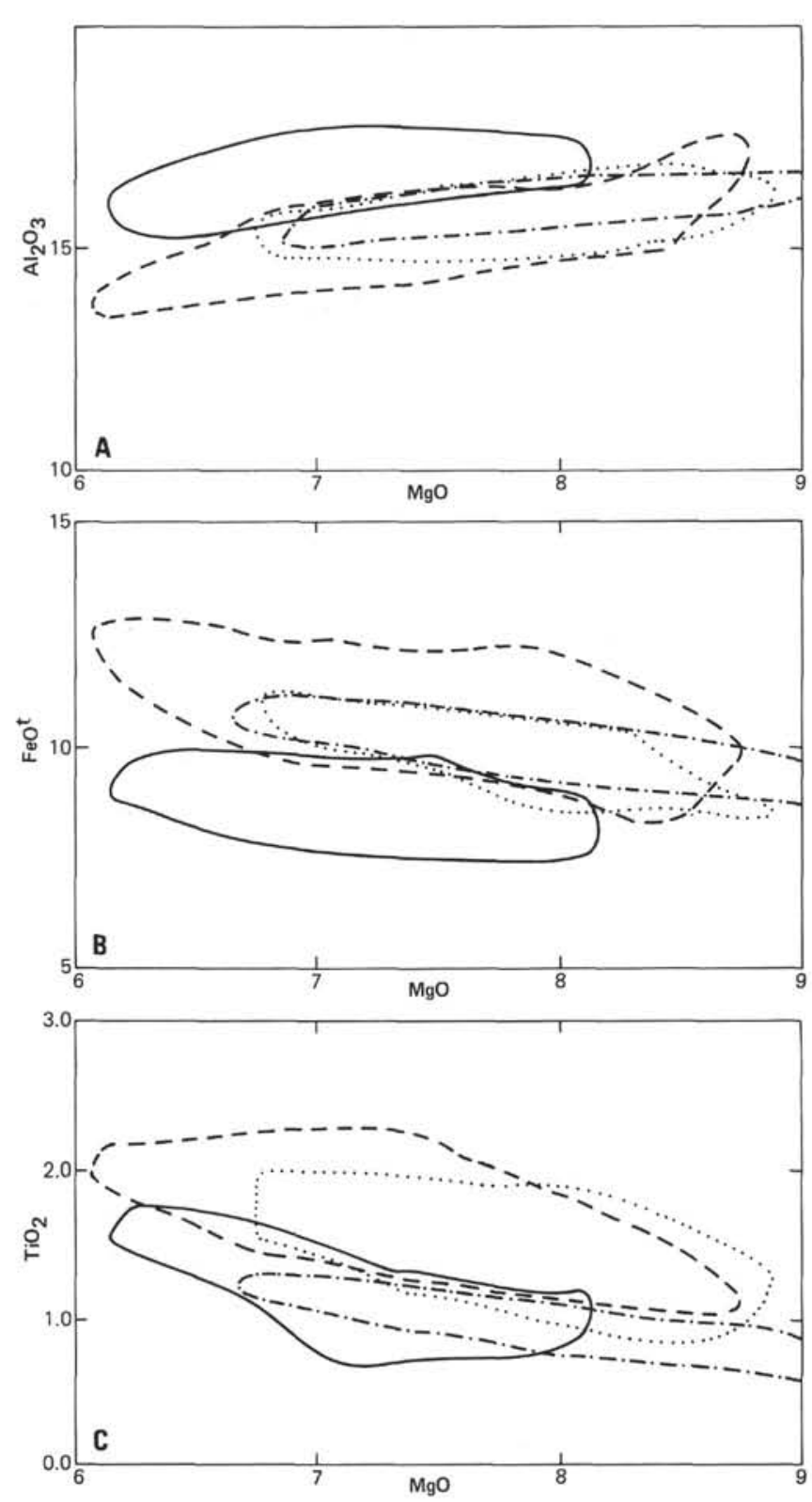

Figure 3. $\mathrm{MgO}$ variation diagrams for $\mathrm{Al}_{2} \mathrm{O}_{3}(\mathrm{~A}), \mathrm{FeO}^{\mathrm{t}}(\mathrm{B})$, and $\mathrm{TiO}_{2}$ (C) for fields of basaltic glasses from back-arc basins: Mariana Trough, Parece Vela Basin, Lau Basin, and the Scotia Sea (solid line), normal segments of the Mid-Atlantic Ridge (dotted line), East Pacific Rise (dashed line), and the FAMOUS area (dashed and dotted line).

analyzed data or are analyzing glass samples for volatile content is associated with a convergent plate boundary. Presumably, active spreading in the Parece Vela Basin was associated with subduction of Pacific oceanic lithosphere before the opening of the Mariana Trough (Scott et al., in press). Volatile constituents of the subsiding oceanic plate are likely to permeate the overlying mantle to some extent. The Mariana Trough is a narrow basin and the subduction zone lies close to the spreading center. Thus volatiles in the basaltic glasses from that basin may more readily be assumed to originate in the subducted slab. In other back-arc basins, such as the Scotia
Sea, the Benioff zone is much farther from the spreading center (see, for example, Barker, 1970). It is possible that convection patterns set up in the mantle above the subsiding plate (see Andrews and Sleep, 1973; Toksöz and Bird, 1977) could account for the lateral transport of volatiles necessary to enrich the regions below the spreading centers of such basins.

Analysis of existing trace element data collected so far impose several possible constraints on the nature and previous melting history of $\mathrm{BAB}$ lavas. The Mariana Trough glasses do not show the light REE depletion characteristic of normal MORB (Fig. 4). Patterns of REE for Mariana Trough glass and Scotia Sea whole-rock analyses are essentially flat relative to chondrites. and lie near the upper limit of the field of MORB at 15 to 20 times chondritic abundances.

If the sources of the lavas erupted in these back-arc basins had not been subject to previous episodes of melting they should have retained a primordial "chondritic" pattern of REE abundances. Basaltic liquids derived at high degrees of melting of such an undepleted source would be slightly enriched in light REE (Philpotts et al., 1972; Schilling, 1975b; Yoder, 1976). Relative enrichment in light rare earths is characteristic of "plume"' magmas (Schilling, 1973a, 1973b, 1975a) with an undepleted source region different from and presumably deeper than the source region for normal MORB. The Philippine Sea plate is composed of normal MORB, depleted in light REE (Mattey et al., in press; Scott et al., in press). Thus the mantle source of those lavas has undergone at least one episode of melting. In order to produce magmas with chondritic REE patterns in a marginal basin formed adjacent to the Philippine Sea, a previously undepleted source, possibly material from deeper in the mantle, might be required.

Chondritic REE patterns can also occur in lavas produced from a very small degree of partial melting of a source that has experienced a previous episode of melting. The light REE are more strongly partitioned into a liquid in equilibrium with the common rock forming minerals (except for plagioclase) than are the heavy REE (Schnetzler and Philpotts, 1970). The concentration of a given REE in a liquid may be calculated according to the relationship presented by Schilling (1975b, Appendix I):

$$
C_{L}{ }^{i}=\frac{C_{P}{ }^{i}}{Y\left(\sum_{j=i}^{j=n} K_{j}^{i} E_{j}\right)+\sum_{j=i}^{j=n} K_{j}^{i} X_{j}},
$$

where

$$
\begin{aligned}
i & =\text { rare earth element, } \\
j & =\text { phase, } \\
C_{L}= & \text { concentration of rare earth element in } \\
& \text { liquid, } \\
C_{p}= & \text { concentration of rare earth element in } \\
& \text { parent material, }
\end{aligned}
$$




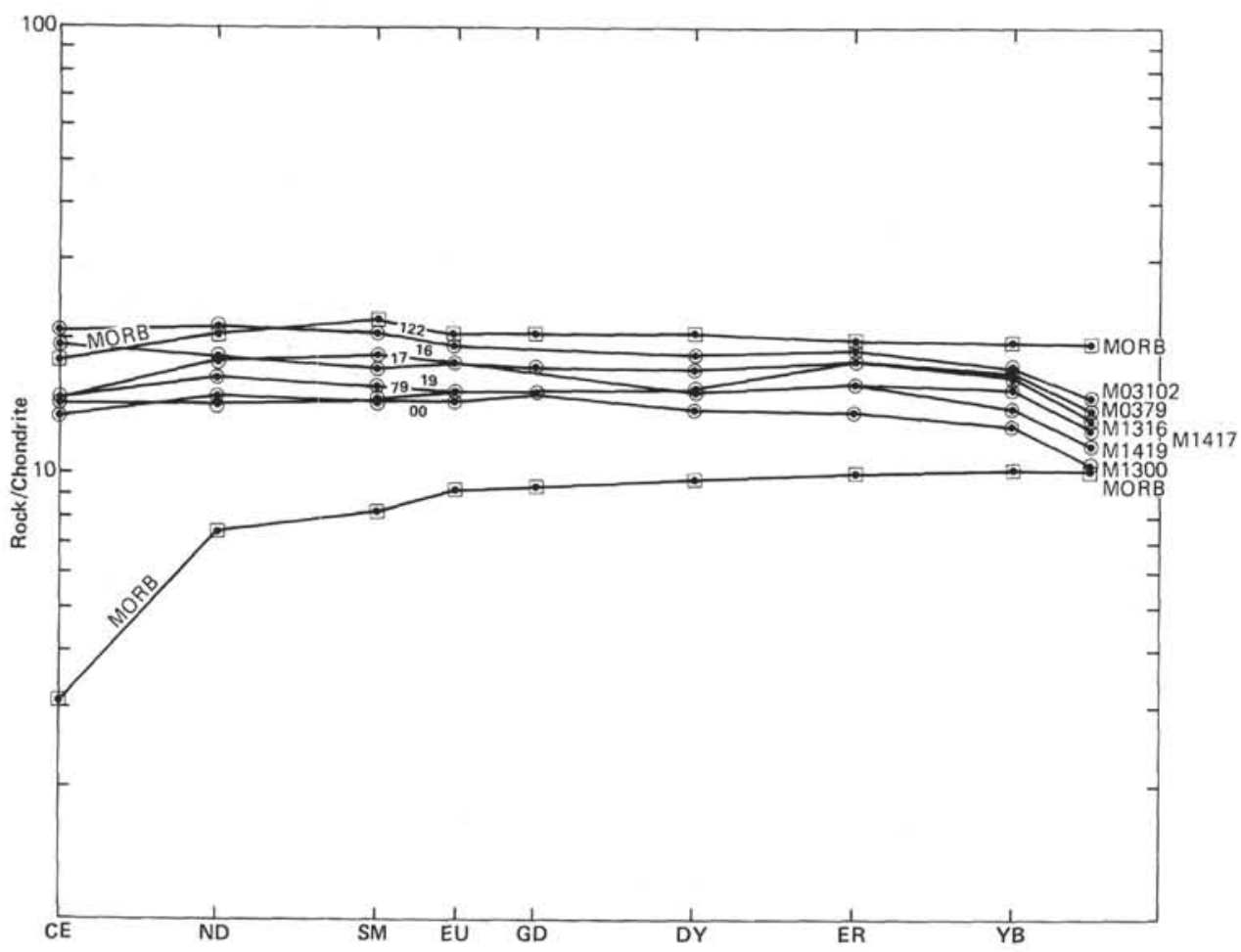

Figure 4. Chondrite normalized values of rare earth elements for six basaltic glasses from the Mariana Trough (circles) compared with the range of values for N-type MORB (squares).

$$
\begin{aligned}
Y= & \text { weight fraction of liquid (degree of } \\
& \text { melting), } \\
K= & \text { partition coefficient between residual phase } \\
& \text { and liquid, } \\
E= & \text { eutectic proportion in weight percent of } \\
& \text { phase } j, \text { and }
\end{aligned}
$$

From this relationship it can be seen that a very small amount of liquid in equilibrium with a light-REEdepleted source could segregate to produce a magma with a chondritic pattern. Even slightly greater amounts of melting would alter the REE signature considerably, however. It is unlikely that the marginal basin basalts represent such very small degrees of partial melting, since overall abundances fall within the field of $\mathrm{N}-\mathrm{MORB}$, and generation of MORB requires approximately 20 to $30 \% \cdot$ partial melting (Schilling, 1975b).

The patterns of REE abundances in rocks are influenced by the mineralogy of the source as well as by its melting history. The solid-liquid partition coefficients $\left(C_{S} / C_{L}\right)$ of heavy REE in pyroxene and garnet are greater than those in the light REE, olivine shows little difference, and plagioclase is the only common rockforming mineral in which $C_{S} / C_{L}$ is greater for the light REE than for the heavy REE (Schnetzler and Philpotts, 1970). If plagioclase were an important component in the source of $\mathrm{BAB}$, there should be a noticeable positive Eu anomaly in MBB lavas, since Eu is strongly partitioned into plagioclase. No such anomaly is present in our data.
Another indication of the character of the source derives from the incompatible element ratios of the Mariana Trough glasses (Table 3). These indicate that the source for $\mathrm{BAB}$ is indeed different from that of $\mathrm{N}-\mathrm{MORB}$. Ba concentration in the $\mathrm{BAB}$ samples is higher than that of MORB, and ratios of $\mathrm{K} / \mathrm{Ba}, \mathrm{Ce} / \mathrm{Ba}$, $\mathrm{Sr} / \mathrm{Ba}$, and $\mathrm{K} / \mathrm{Rb}$ are lower than for N-MORB. $\mathrm{Rb}$ is depleted with respect to $\mathrm{Sr}$ in $\mathrm{BAB}$ lavas, indicating that the source for $\mathrm{BAB}$ may have experienced loss of melt in some previous event. Isotope ratios ${ }^{87} \mathrm{Sr} /{ }^{86} \mathrm{Sr}$ values from Mariana Trough basalts range from 0.7026 to 0.7029 (Hart et al., 1972; Meijer, 1976; Melchior and Hawkins, 1980), also implying a previous depletion event. The higher concentrations of $\mathrm{Sr}, \mathrm{Ba}, \mathrm{Rb}$, and light REE in $\mathrm{BAB}$ relative to N-MORB probably reflects a later enrichment of the $\mathrm{BAB}$ source region with these elements.

It is obvious that interpretation of the present data is inconclusive regarding history of the source material for BAB magmas. One method which has proven useful for determining previous melting history of mantle source regions is Nd isotope studies (DePaolo and Wasserburg, 1976; O'Nions et al., 1977). We have selected samples representative of the range of rare earth values among the Mariana Trough glasses for Nd isotope analysis. These analyses will be completed shortly.

\section{CONCLUSIONS}

The data presented here, although preliminary, do permit several conclusions concerning the composition and generation of basalts in active back-arc basins: (1) Fresh basaltic glasses from all the active back-arc basins studied are similar in major and trace element composi- 
tions. (2) They differ from MORB in having higher $\mathrm{Al}_{2} \mathrm{O}_{3}$ and lower $\mathrm{FeO}^{t}$ for a given $\mathrm{MgO}$ concentration. Trace element abundances in the BAB lavas are more like P-MORB than N-MORB in having relatively higher concentrations of light REE and incompatible elements and lower ratios of $\mathrm{K} / \mathrm{Ba}, \mathrm{Ce} / \mathrm{Ba}, \mathrm{Sr} / \mathrm{Ba}$, and $\mathrm{K} / \mathrm{Rb}$. (3) With respect to $\mathrm{Sr}, \mathrm{K}, \mathrm{Ba}$, and $\mathrm{Rb}$ concentrations, the sources for basalts from active back-arc basins are more like those of mantle plumes or hot spots than normal ridge segments. The sources for $\mathrm{BAB}$ are not as enriched in light REE as those of plume basalts, however probably the enriched lithophile elements $\mathrm{Sr}, \mathrm{K}, \mathrm{Ba}$, and $\mathrm{Rb}$ and light REE concentrations reflect enrichment of the source regions of $\mathrm{BAB}$ with these elements. (4) The source of the volatile and enriched lithophile elements is problematic, but we feel that hydrous fluids or vapors derived from the subsiding oceanic lithospheric plate may enrich the source regions of $\mathrm{BAB}$ magmas with these elements.

\section{ACKNOWLEDGMENTS}

We would like to express our thanks to the shipboard personnel on the Kana Keoki and Glomar Challenger for their assistance in procuring the samples from the Mariana Trough. Andrew D. Saunders provided the glass samples from the Scotia Sea. We thank Timothy O'Hearn, who performed the microprobe analyses of the glasses at the Smithsonian Institution. We are grateful to Gerard J. Fryer for his assistance in the computer programming required for the analysis and interpretation of the data and to James Natland, Charles Langmuir, and Robert Stern for their helpful comments on this paper.

This work was supported by the National Science Foundation under Grant No. OCE78-09034. The chapter is Hawaii Institute of Geophysics Contribution No. 1149.

\section{REFERENCES}

Ambos, E. L., 1980. Crustal structure of the Mariana Trough from seismic refraction data [M.S. thesis]. University of Hawaii.

Ambos, E. L., and Hussong, D. M., 1979. Crustal structure of the Mariana Trough. EOS, 60(18):389. (Abstract)

Andrews, D. J., and Sleep, N. H., 1973. Numerical modelling of tectonic flow behind island arcs. Geophys. J. Roy. Astr. Soc., $38: 237-251$.

Aumento, F., 1968. The Mid-Atlantic Ridge near $45^{\circ} \mathrm{N}$. II. Basalts from the area of Confederation Peak. Can. J. Earth Sci., $5(1): 1-21$.

Barker, P. F., 1970. Plate tectonics of the Scotia Sea region. Nature (London), 228:1293-1297.

Byerly, G. R., Melson, W. G., Nelen, J. A., et al., 1975. Abyssal basaltic glasses as indicators of magma compositions. In Mason, B. (Ed.), Mineral Sciences Investigations, Smithsonian Contributions to the Earth Sciences, 19:22-30.

DePaolo, D. J., and Wasserburg, G. J., 1976. Nd isotopic variations and petrogenetic models. Geophys. Res. Lett., 3:249.

Engel, A. E. J., and Engel, C. G., 1964. Composition of basalts from the Mid-Atlantic Ridge. Science, 144:1331-1333.

Engel, A. E. J., Engel, C. G., and Havens, R. G., 1965. Chemical characteristics of oceanic basalts and the upper mantle. Geol. Soc. Am. Bull., 76:719-734.

Fryer, P., 1980. Composition and petrogenesis of basalt in the Mariana Trough, an active back-arc basin. 26th Intl. Geol. Congr., $1: 44$. (Abstract)

Garcia, M. O., Liu, N. W. K., and Muenow, D. W., 1979. Volatiles in submarine volcanic rocks from the Mariana island arc and trough. Geochim. Cosmochim. Acta, 43:305-312.

Gill, J. B., 1976. Composition and ages of Lau Basin and Ridge volcanic rocks: Implications for evolution of inter-arc and remnant arc. Geol. Soc. Am. Bull., 87:1384-1395.

Green, T. H., and Ringwood, A. E., 1968. Genesis of the calc-alkaline igneous rock suite. Contrib. Mineral. Petrol., 18:105-162.
Hamilton, W., 1964. Origin of high alumina basalt, andesite, and dacite magmas. Science, 146:635-637.

Hart, S. R., Glassley, W. E., and Karig, D. E., 1972. Basalts and seafloor spreading behind the Mariana Island arc. Earth Planet. Sci. Lett., 15:12.

Hawkins, J. W., 1974. Geology of the Lau Basin, a marginal sea behind the Tonga Arc. In Burke, C., and Drake, C. (Eds.), Geology of Continental Margins: Berlin (Springer-Verlag), pp. 505-520. 1976a. Petrology and geochemistry of basaltic rocks of the Lau Basin. Earth Planet. Sci. Lett., 218:283-297. 1976b. Petrology of the Lau Basin basalts: Oceanic crust of a marginal basin. EOS, 57:410. (Abstract) 1977. Petrology and geochemical characteristics of marginal basin basalt. In Talwani, M., and Pitman, W. C. (Eds.), Island Arcs, Deep Sea Trenches, and Back-Arc Basins: Washington (Am. Geophys. Union), pp. 355-365.

Hawkins, J. W., and Batiza, R., 1975. Tholeiitic basalt from an active spreading center on the North Fiji Plateau $15^{\circ} 30^{\prime} \mathrm{S}, 173^{\circ} 30^{\prime} \mathrm{E}$. EOS, 56:1078. (Abstract)

Hussong, D. M., and Fryer, P., 1980. Tectonic evolution of the marginal basins behind the Mariana Arc. Geol. Soc. Am. Abstracts with Programs, 12:1112. (Abstract)

Hussong, D. M., and Sinton, J. B., 1979. Low-level seismicity in the Mariana Trough. EOS, 60(46):877. (Abstract)

Kay, R., Hubbard, N. J., and Gast, P. W., 1970. Chemical characteristics and origin of oceanic ridge volcanic rocks. J. Geophys. Res., 75:1585-1613.

Langseth, M. G., and Mrozowski, C., in press. Geophysical surveys for Leg 59 sites. In Kroenke, L., Scott, R., et al., Init. Repts. DSDP, 59: Washington (U.S. Govt. Printing Office), 487-502.

Mattey, D., Marsh, B., and Tarney, J., in press. The geochemistry, mineralogy, and petrology of basalts from the West Philippine and Parece Vela basins and from the Palau-Kyushu and West Mariana ridges, Deep Sea Drilling Project Leg 59. In Kroenke, L., Scott, R., et al., Init. Repts. DSDP, 59: Washington (U.S. Govt. Printing Office), 753-800.

Meijer, A., 1976. $\mathrm{Pb}$ and $\mathrm{Sr}$ isotope data bearing on the origin of volcanic rocks from the Mariana island arc system. Geol. Soc. Am. Bull., 87(9):1359-1369.

Melchior, J., and Hawkins, J., 1980. Petrology of Mariana back-arc basin basalt. EOS, 61(46):1143.

Melson, W. G., Vallier, T. L., Wright, T. L., et al., 1976. Chemical diversity of abyssal volcanic glass erupted along the Pacific, Atlantic and Indian Ocean sea-floor spreading centers. In Sutton, G. H., Manghnani, M. H., and Moberly, R. (Eds.), The Geophysics of the Pacific Ocean Basin and its Margins: Washington (Am. Geophys. Union), Mon. 19:351-367.

Miyashiro, A., Shido, F., and Ewing, M., 1970. Crystallization and differentiation in abyssal tholeiites and gabbros from mid-ocean ridges. Earth Planet. Sci. Lett., 7:361-365.

O’Nions, R. K., Hamilton, P. J., and Evensen, N. M., 1977. Variations in ${ }^{143} \mathrm{Nd} / 144 \mathrm{Nd}$ and ${ }^{87} \mathrm{Sr} /{ }^{86} \mathrm{Sr}$ ratios in oceanic basalts. Earth Planet. Sci. Lett., 34:13-22.

Philpotts, J. A., Schnetzler, C. C., and Thomas, H. H., 1972. Petrogenetic implications of some new geochemical data on eclogite and ultra basic inclusions. Geochim. Cosmochim. Acta, 36:1131-1166.

Sager, W. W., 1980. Structure of the Mariana Arc inferred from gravity and seismic data. J. Geophys. Res., 85:5382-5388.

Saunders, A. D., Tarney, J., Weaver, S. D., et al., in press. Scotia Sea floor: Geochemistry of basalts from the Drake Passage and South Sandwich spreading centers. In Craddock, C. (Ed.), Antarctic Geoscience: Madison (University of Wisconsin Press).

Schilling, J.-G., 1973a. Iceland mantle plume: Geochemical evidence along Reykjanes Ridge. Nature (London), 242(5400):565-571.

, 1973b. Afar mantle plume: Rare-earth evidence. Nature (London) Phys. Sci., 142(114):2-5.

1975a. Azores mantle blob: Rare-earth evidence. Earth Planet. Sci. Lett., 25:103-115.

1975 b. Rare earth variations across "Normal Segments" of the Reykjanes Ridge, $60^{\circ}-53^{\circ} \mathrm{N}$, Mid-Atlantic Ridge, $29^{\circ} \mathrm{S}$, and East Pacific Rise, $2^{\circ}-19^{\circ} \mathrm{S}$, and evidence on the composition of the underlying low-velocity layer. J. Geophys. Res., 80(11): 1459-1473.

Schnetzler, C. C., and Philpotts, J. A., 1970. Partition coefficients of rare-earth elements between igneous matrix material and rock 
forming mineral phenocrysts-II. Geochim. Cosmochim. Acta, $34: 331-340$.

Schnetzler, C. C., Thomas, H. H., and Philpotts, J. A., 1967. Determination of rare-earth elements in rocks and minerals by mass spectrometric, stable isotope dilution technique. Anal. Chem., 39:1888-1890.

Schuhmann, S., Philpotts, J. A., and Fryer, P., 1980. Suppression of monoxide interference in surface ionization mass spectrometry of rare-earth elements. Anal. Chem., 52:214-216.

Scott, R., Kroenke, L. W., Zakariadze, G., et al., in press. Evolution of the South Philippine Sea: Deep Sea Drilling Project Leg 59 Results. In Kroenke, L., Scott, R., et al., Init. Repts. DSDP, 59: Washington (U.S. Govt. Printing Office), 803-816.

Sun, S. S., Nesbitt, R. W., and Sharaskin, A. Ya., 1979. Chemical characteristics of mid-ocean ridge basalts. Earth Planet. Sci. Lett., 44:119-139.

Tarney, J., Saunders, A. D., and Weaver, S. D., 1977. Geochemistry of volcanic rocks from the island arcs and marginal basins of the
Scotia Sea region. In Talwani, M., and Pitman, W. C. (Eds.), Island Arcs, Deep Sea Trenches and Back-Arc Basins: Washington, (Am. Geophys. Union), pp. 367-377.

Toksoz, M. N., and Bird, P., 1977. Formation and evolution of marginal basins and continental plateaus. In Talwani, M., and Pitman, W. C. (Eds.), Island Arcs, Deep Sea Trenches and Back-Arc Basins: Washington (Am. Geophys. Union), pp. 379-393.

Uyeda, S., and Hussong, D. M., 1978. General results of DSDP Leg 60 , the eastern portion of the South Philippine Sea transect along $18^{\circ}$ N. EOS, 59(12):1179. (Abstract)

Webster, R. K., 1960. Mass spectrometric isotope dilution analysis. In Smales, A. A., and Wager, L. R. (Eds.), Methods in Geochemistry: New York (Interscience), pp. 202-246.

White, W. M., and Bryan, W. B., 1977. Sr-isotopes, K, Rb, Cs, Sr, $\mathrm{Ba}$, and rare-earth geochemistry of basalts from the FAMOUS area. Geol. Soc. Am. Bull., 88(4):570-586.

Yoder, H. S., 1976. Generation of Basaltic Magma: Washington (National Academy of Sciences), p. 155. 